\title{
Children into Adults, Peasants into Patriots: The Army and Nation-Building in Serbia and Bulgaria (1878-1912)
}

\author{
Naoum Kaytchev
}

\section{Introduction}

After the Great Eastern Crisis of $1875^{-1878}$ and the Berlin Congress of 1878 , Bulgaria and Serbia respectively were acknowledged as autonomous and independent states, thus moving further out from the Ottoman political orbit. In the two countries, processes of nation-building proceeding efficiently, with army systems playing an important role: a large proportion of young men were called up and exposed to intensive training in new nationalist molds. In both countries, they were conscripted around the age of $20^{1}$ — the period that marks the transition from childhood/youth status to that of adulthood.

1 In Bulgaria, the conscription age was consistently lowered. Initially, youngsters were recruited after turning 21 in the calendar year previous to the recruitment, but from 1892 this age was reduced to 20, and from 1904 reduced further to 19. Thus, for example, boys born in 1885 were recruited in the spring of 1905 , several months before or after turning 20 years old. Secondary school pupils and university students were conscripted after graduation. See: Article 4, "Law on Taking New Recruits in the Bulgarian Army," Dărzhaven vestnik, 2 (89), December 6, 1880; Article 15, "Law on the Organization of the Military Forces of the Bulgarian Army," id. 14 (36), February 15, 1892; Article 13, "Law on the Organization of the Military Forces of the Bulgarian Army," id. 14 (18), January 24, 1904.

In Serbia, males were initially conscripted after turning 20 years in the calendar year previous to the recruitment, but in 1884 this age dropped by one year. Towards 1899, the age of conscripts was raised back up again. Thus, for example, Belgrade boys born in 1870 were conscripted in September 1890; those born in 1878, in March 1899; and those born in 1883, in August 1904. In both countries secondary school pupils and university students (a tiny minority among conscripts) were recruited after their graduation and served reduced terms of duty. See: Article 5, "Law on the Recruitment of the Permanent Army, October 23, 1872," in Zbornik zakona i uredaba izdanih u Knjažesvu Srbiji (Belgrade: State Printing House, 25, 1872), 63; Article 3, "Law on the Organization of the Army," Srpske novine, 50 (24), 115, February 1, 1883; "Naredba okružne komande," Beogradske opštinske novine, 8 (33), August 5, 1890; "Objava," Beogradske opštinske novine, 17 (9), March 7, 1899; Article 2, "Law on the Organization of the Army, January 27, 1901," in Zbornik zakona i uredaba u Kraljevini Srbiji (Belgrade: State Printing House, 61, 1903), 92-93; "Law on the Amendment of the Law on the Organization of

(C) NAOUM KAYTCHEV, 2016 | DOI 10.1163/9789004305809_007

This is an open access title distributed under the terms of the Creative Commons Attribution- 
While traditional peasant societies tended to associate men's maturity with marriage, ${ }^{2}$ the new Serbian and Bulgarian states started to prescribe more precise juridical definitions. The Serbian Civil Code, first adopted by the Principality of Serbia in 1844 and still in use even after the Second World War, considered all persons under 21 years as of 'youth-age' [mladoletni] and classified them as either 'small children' [under age of seven], 'ungrown children' [deca nedorasla, age of seven to 14] or 'grown-up children' [deca dorasla, above age of 14, under 21]. ${ }^{3}$ Similarly, Bulgaria's 1879 Tărnovo Constitution provided political voting rights only for citizens above the age of $21 .{ }^{4}$ Respective provisions were also inscribed in Bulgaria's civil law as well: a special law on guardianship defined as minors ('underage person') all individuals under the age of 21; the designation 'underage children' (nepălnoletni detsa) was also used as a synonym. Minors were prohibited from controlling property or entering into property transactions, which were the responsibility of their father (or in the case of his death, of a guardian and special council of relatives, which included also the local judge). ${ }^{5}$ In this context, for a large portion of the population,

the Army, April 15, 1902," Službeni vojni list, 22 (16), April 20, 1902, 301; “Objava," Beogradske opštinske novine, 22 (36), August 22, 1904.

2 Traditionally, family law was governed by the religious rules of the various denominations. According to the Statute of the Bulgarian Exarchate (applied over the majority Eastern Orthodox population) the minimum marriage age for boys was 20 years, and for girls 18 years. See: Article 186, Sixth Part of the "Exarchate's Statute Adapted for the Principality of Bulgaria," in Velichko Georgiev and Stayko Trifonov, Istoriya na bălgarite 1878-1944 v dokumenti, 1 (1) (Sofia: Prosveta, 1994), 213.

3 Article 37 in ibid., 11. There were some modifications and exceptions to this rule: girls above the age of 18 could marry without consent of the parents (Article 150); boys above the age of 17 could be proclaimed adults by a court after a personal and parental application, but even in this case the law instructed judges to consider if there were essential grounds for such a decision: 'the male [person] is wedded, maintains own house, regularly runs craft or trade, or has received a position in the public service with a regular salary' (Article 152 , Ibid., 51-52).

4 Herbert Wright, The Constitutions of the States at War 1914-1918 (Washington, DC: Government Printing Office, 1919), 96.

5 "Law on Guardianship," Dărzhaven vestnik, 12 (67), 1-5, March 24, 1890. See especially Articles $1-3$ and $14-15$. The law provided that above 18 years of age, in some cases "an underage person" could be put under milder form of supervision (popechitelstvo): he could use profits from his property, but still not sell it or use it for credit without the approval of the council of relatives (Articles 100-111). Other important childhood-related civic legal acts were the "Law on Acknowledgement of Illegitimate Children, of their Legitimization and on Adoptions," Dărzhaven vestnik, 12 (9), January 12, 1890, and the "Law on Inheritance," Dărzhaven vestnik, 12 (20), January 25, 1890. 
especially peasants, conscription marked the effective transition of the male from the world of childhood, understood in the wider sense of immaturity ${ }^{6}$ and legal minority, to that of adulthood. This was hardly a unique experience: in many other countries on the continent 'growing up' implied a similar army encounter. ${ }^{7}$ At the same time, the school systems of both states were involved in parallel educational nation-building process, aimed at children of different age groups.

In what follows I will present and analyze the role of military systems in forging and affirming modern Serbian and Bulgarian national identities and the suggested types of national identity imposed on the young conscriptsturned-adults. These messages will be compared with those of the schools, targeted at younger children. Some recent theories on nationalism would be applied, mostly implicitly, in the process. ${ }^{8}$

\section{Creating Soldier-Citizens}

The two countries aimed to build strong armies as a strategic priority. The reasons for this were concerned mainly with questions of 'grand policy' and war: Serbia and Bulgaria sought to put up capabilities that could not only defend their borders, but also secure enlargement by acquisition of new 'unredeemed' territories. Though the two states were sometimes rivals, and on one occasion in 1885 even went to war, their main focus, especially in later decades, was on the remaining Ottoman possessions in Europe. This course was reflected in the

6 Similarly, many other contemporary Europeans tended to regard childhood as also encompassing the phase of adolescence: see Michelle Perrot, Philippe Ariès and Georges Duby (eds), A History of Private Life: From the Fires of Revolution to the Great War (Harvard: Harvard University Press, 1990), 203.

7 Cf. Colin Heywood, Growing Up in France: From the Ancien Régime to the Third Republic (Cambridge: Cambridge University Press, 2007), 83-85, 268.

8 Some of the arguments in this chapter are drawn from the relevant sections of my book: Naoum Kaytchev, Makedoniyo, văzzhelana: armiyata, uchilishteto i gradezhăt na natsiyata $v$ Sărbiya i Bălgariya [Desired Macedonia: Army, School and Nation-Building in Serbia and Bulgaria, 1878-1912] (Sofia: Paradigma, 2003; 2nd edition, 2006). It is hardly possible in this space to engage extensively in the ongoing debates and plethora of theories concerning nationalism. I would point here to a seminal article: Anthony Smith, "Gastronomy or Geology? The Role of Nationalism in the Reconstruction of Nations," Nations and Nationalism, 1, 1995, 3-23. Cf. Umut Özkirimli, Theories of Nationalism: A Critical Introduction (New York: Palgrave Macmillan, 2010). 
financial policy of the two states, with the lion's share of the state budget earmarked for the military. ${ }^{9}$

One important aspect of the army modernization in Serbia involved the complete transformation of the old principality's main body of militiamenpermanently armed peasants called periodically in the army-into conscript soldiers. Immediately after the Berlin Congress, in the autumn of 1878 Belgrade tripled its nucleus of conscription-based units, and five years later a new army law scrapped the militia system altogether and promulgated universal military duty. The implementation of the law amounted to radical intervention over Serbian society. In some eastern parts of the country a great number of peasants refused to surrender their arms and occupied four eastern counties, including their central towns. This Timochka buna [Timok Uprising] of 1883 was in military terms a clash of old militia units with the new conscript-based army, and the ultimate supremacy of more disciplined new detachments proved the necessity of the reform. ${ }^{10}$ In contrast, Bulgaria, lacking any immediate previous state and with no militia system, experienced no opposition after 1878 to building its army on a modern conscription basis. The creation of these large modernized armies involving large segments of the male population also led to changing societal patterns of states and societies, as conscripts were forced to abandon their usual pace of life and spend a one-and-a-half to two years (and in certain cases, even three years) in the army.11

Legally, all males were subject to conscript service. However, in practice, high birth rates meant that the number of adolescents far outnumbered the army's capacity. A substantial number of youths were not recruited, officially

In Bulgaria, on average approximately $25 \%$ (between $16 \%$ and $44 \%$ over the years) of the state budget was devoted to the War Ministry, and in Serbia over $20 \%(17 \%-20 \%$, plus additional expenditures for arms procurement). The proportion of military expense in terms of real post-balance payments was even higher if one takes into account the large portion (15-25\% in Bulgaria, even more in Serbia) used to service the state foreign debt. See Statisticheskigodishnikna Bălgarskoto tsarstvo (Sofia: Glavna Direktsiya na Statistikata [Directorate General of Statistics]), 4:1912, 356-357; Statistički godišnjak Kraljevine Srbije 4: 1898-1899 (Belgrade: Državna Štamparija Kraljevine Srbije, 1902), 440; id., 12: 1907-1908 (id. 1913), 583-588.

10 Slavica Ratković-Kostić, "Stvaranje stajače vojske u Srbiji i njena uloga u Timočkoj buni 1883 godine,"Vojinoistorijski glasnik, 44 (1-2), 1996, 24-29; Milić Milićević, “Vitalni činioci razvoja srpske vojske tokom XIX veka," Vojinoistorijski glasnik, 41 (1-2), 1993, 45-55.

11 In both countries infantry service was initially for two years, although in Serbia in 1901 it was reduced to 18 months. Artillery and cavalry service was for three years in Bulgaria and two years in Serbia. In both countries, secondary school pupils and university students or graduates were subjected to shortened terms of military duty. 
for medical, family or other reasons. According to annual statistics, between only $27 \%$ and $52 \%$ of Bulgarian males went to the barracks, ${ }^{12}$ and although there are no clear comparable data on Serbia, the relation of army numbers to the general population suggests that a similar percentage of the youth was recruited.

Nevertheless, a substantial proportion of young Bulgarian and Serbian youths made their first steps outside the familiar world of the local group in the army, where they had to interact within larger and novel complex communities. The social break was even more important because of the origin of the recruits: the populations of both countries were overwhelmingly peasant $(80-81 \%$ in Bulgaria and $86-87 \%$ in Serbia), and the corresponding majority of the soldiers came from villages. They were intensively exposed to new perspectives and ideas: the armies undertook a process of 'moral training' of the soldiers, making conscripts into patriots who believed in their belonging to the nation and who were expected to sacrifice themselves for it. In the time leading up to the Balkan Wars of 1912-1913, more emphasis was placed on this training.

Most of the conscripts were not entirely new to the sustained institutional influence of the state: as seven- or eight-year-old children they were 'recruited' in the elementary school. Bulgaria in 1880 and Serbia in 1882 adopted special laws proclaiming compulsory primary education, ${ }^{13}$ and made some efforts towards achieving this aim. The reports of school inspectors, especially in Serbia, demonstrate peasant passivity towards these modernization attempts:

If some [parents] seemingly willingly give their children to the school, it is not because they see benefit from the education, but because they know that they should send their children to school, just like in the army. They usually think that the child should 'serve' in the school four years.

When approached to send their children for further studies, the usual parents' answer was: "my child has already served four years, it doesn't need more."14

12 Statisticheskigodishnik, 5-14:1913-1922 (Sofia:Glavna Direktsiya na Statistikata [Directorate General of Statistics], 1924), 110-111, 114.

13 "Law on Material Support and Educational Rearrangement of Schools, May 21, 1880," Dărzhaven vestnik, 2 (45) May 28, 1880; "Law on Primary Schools, December 31, 1882," Prosvetni glasnik, 4 (2), January 31, 1883, 41-51. Compulsory primary education was introduced simultaneously with France, in 1882: Eugen Weber, Peasants into Frenchmen: The Modernization of Rural France 1870-1914 (Stanford: Stanford University Press, 1976), 309.

14 Ministry of Education, "Report on the Elementary Schools in Four Counties of the Požarevac District in 1902-1903 School Year," July 20, 1903, 46-76 (Archive of Serbia). 
Thus large numbers of girls, and even more of boys, attended mainly the first few grades: at the turn of the twentieth century approximately $32 \%$ of Serbian and $58 \%$ of Bulgarian conscripts were literate, while on the eve of the Balkan Wars this had increased to $57 \%$ and $82 \% .^{15}$ All pupils were exposed to the nation-building influences of the primary school system, although only a tiny minority ( $2 \%$ in Serbia and $8-14 \%$ in Bulgaria) of school 'conscripts' continued to some form of secondary education.

In both countries the officers were the face of the army, its most visible and representative element. They were a comparatively small group-not more than 2,000-3,000 individuals in each country-but by their standing and influence they were a clearly distinguished body among the motley mosaic of latenineteenth-century Balkan societies. In moral, ideological and propaganda terms the officers were publicly praised by politicians, journalists and publicists as the people's hope for the defense of the fatherland and for future national unification. Such rhetoric would have had doubtful success, had it not been financially underpinned; both young nation-states provided generous salaries for their military.

The social background of the higher ranks differed sharply from the peasant mass of the soldiers that they commanded, shaped and educated: $84 \%$ of Bulgarian and $76-79 \%$ of Serbian officers were of urban bourgeois origin. The graduates of civil high schools and universities - the human base of the political, administrative, cultural and economic elites-were conscripted in special military training units and commissioned as reserve officers. Numerous links bound the higher ranks with leading business, political and cultural strata. The 'pre-planned creation of the elite' even included specific marital regulations: according to special laws, a Serbian officer could marry a prospective wife only with the approval of his direct superior officer and the Minister of War. According to the law, junior officers also had to show they had extra income apart from their salaries: 2,000 dinars (equal at the time to French francs and Bulgarian leva) for lieutenants, 1,500 or 1,000 dinars in the case captains. Only majors could marry without such a precondition. ${ }^{16}$ In Bulgaria legal requirements were somewhat lighter, but similar: officers were forbidden to marry until 25 years of age, and between 25 and 28 years old they had to show

15 Id., "Percentage of Literate Soldiers According to Different Army Branches in 1912," July 7 , 1912, 75-95 (Archive of Serbia); Statisticheski godishnik, 110; Statistički godišnjak, 698.

16 This societal everyday pattern was reflected in Serbian literature: an army captain of modest background dreams to marry his beloved peasant girl, but this could be realized only by passing through the hurdles of the exam for the rank of major. This story was the central theme of the short novel Captain Marjan, by the Serbian classic writer Stevan Sremac. 
that they had an extra-salary income of 1,200 leva. It should be noted that this was not some unique Balkan requirement: the two states were following a practice universally applied by major European armies; and as a result, military and civil elites were closely intertwined: in Serbia, only four out of 1,876 officers married peasant girls. ${ }^{17}$

The special role of officers included crucial social functions: they served as transmitters of the values that would convert the peasant, heretofore closed in the traditional world of the village, into an active soldier-citizen. That soldiercitizen would realize the true dimensions of the fatherland, which no longer ended with the family plot. To different extents - greater in Bulgaria, lesser in Serbia - the officers themselves identified this as a need and worked to develop the ideological system that would be propagated to the soldiers through instruction and education. A key part of this ideology was to draw the borders of the motherland, to make soldiers sensible of the nature of the fatherland and of the dimensions of the larger national entity.

The military employed different means to mold soldiers' views: direct speeches and lectures to the soldiers, formal hours of education in the 'national spirit' in courses for non-commissioned officers, patriotic marches and songs played by military orchestras and sung by the soldiers and their choirs, amateur theatre scenes and amusements, special festivities on the days of the national saints like Saint Sava or Saints Cyril and Methodius, regimental celebrations and so on. Further, the state-inspired 'union of the people with the army' was abundantly manifested at major public events. Cultural-symbolic demonstrations apart, this bond had a business dimension as well, with rich local merchants and entrepreneurs involved in army deliveries.

17 Mile Bjelajac, "Ženidbe oficira srpske i jugoslovenske vojske 1881-1941. Planirano stvaranje elite," Godišnjak za društvenu istoriju [Annual of Social History], 2 (1), 1995, 19-28; Milić Milićević, "Socijalno poreklo oficirskog kadra školovanog u Srbiji od 1850 do 1901 godine," Godišnjak za društvenu istoriju [Annual of Social History] 2 (2), 1995, 200; "Law on the Organization of the Military Forces of the Bulgarian Army," Dărzhaven vestnik, 14 (36), February 15, 1892; "Law on the Organization of the Military Forces of the Bulgarian army," Dărzhaven vestnik, 14 (18), January 24, 1904.

At the turn of the twentieth century the Serbian marriage regulations were somewhat relaxed: captains could marry without demonstrating the financial stability of their prospective wives, while lieutenants' could marry after five years of active service to brides whose families would present a 10-year life insurance for 10,000 dinars. The marriage of sub-lieutenants was forbidden. "Law on Marriage of Officers, Under Officers, Corporals and Privates, December 24, 1901," in Zbornik zakona i uredaba u Kraljevini Srbiji (Belgrade: State Printing House, 61, 1903), 400-404. 
The most complete source for details of this educational process is publications specifically targeted at the soldiers. Bulgaria's War Ministry began to publish an officers' monthly, named Voenen zhurnal, in 1888, and five years later it started another magazine aimed directly at the rank-and file, entitled Voynishka sbirka. Serbia issued its own official military periodical as well: Ratnik, for the officers, from 1879, and Uzdanica, for ordinary soldiers, from 1900. In addition, a specific genre of literature aimed at officers and soldiers also emerged. Although written largely by acting or retired officers, these books were formally unofficial and the result of private initiative. Successful publications that came to occupy this particular niche were reprinted in several editions. In Serbia, the most successful was Vojnički bukvar [Soldier's Primer] by Kosta Jokić, which went through 12 editions between 1893 and 1912. ${ }^{18}$ While several different Bulgarian publications were in wide circulation, towards the end of the period Voynishki drugar [Soldier's Companion] by Vasil Guzhgulov was unrivalled: it was published eight times between 1907-1912. ${ }^{19}$ Despite these market successes, the two countries' respective ministries of war also ensured that their official magazine for the soldiers was widely distributed: while every company of the Bulgarian army received four copies of Voynishka sbirka, in Serbia all non-commissioned officers were obliged to subscribe to Uzdanica. ${ }^{20}$

Meanwhile, the national education in the schools was accomplished through the study of subjects such as history, geography, 'God's law' (religion). However, the most central role was given to the native language and literature. This occupied the bulk of the two countries' curricula, most importantly at the primary-school level that managed to encompass most peasant children. For example, until 1907 Bulgaria's education system devoted 43-44 hours per week to the national language and literature in the first four grades, compared with only three to six to 'fatherland knowledge' (national history and geography); while in Serbia, ${ }^{28-30}$ hours were allotted to Serbian language and only $7^{-12}$ hours to history and geography. ${ }^{21}$ Hence soldiers' books compared mainly

18 Kosta Jokić, Vojnički bukvar (Belgrade: Državna Štamparija 1893; 12th edition, 1911).

19 Vasil Guzhgulov, Voynishki drugar. Uchebnik za mladite voynitsi ot vsichki rodove voyski (Sofia: Balkanska tribuna, 1st edition 1907; 8th edition, 1912).

20 Sistematicheski sbornik na zakonite, ukazite i tsirkulyarite po voennoto vedomstvo ot 1877/78 do 1 yanuarii 1901 g. (Sofia: Glavna Direktsiya na Statistikata [Directorate General of Statistics], 1901), 421, 423; Uzdanica, 1,1901, 161; 5, 1905, 62.

21 Charles Jelavich, South Slav Nationalisms: Textbooks and Yugoslav Union before 1914 (Columbus: Ohio State University Press, 1990), 35-36; Srećko Ćunković, Školstvo i prosveta u Srbiji u XIX veku (Belgrade: Pedagoški muzej, 1971), 134-142, 155-170; Dimo Tsonkov, Razvitie na osnovnoto obrazovanie v Bălgariya ot 1878 do 1928 (Sofia: Ministerstvo na narodnoto prosveshtenie [Ministry of National Education], 1928), 146-147, 232. 
with literature textbooks as invaluable sources for studying the national instruction of children; especially influential were the manuals for primary education, encompassing children in the $7^{-12}$ age group.

\section{Imagining the Fatherland, Making Up the Nation...}

Bulgarian texts for soldiers had an explicit addressee: pre-modern peasant boys entering the unknown adult world of the army barracks. The soldier literature defined the social and spatial limits of the reader's outlook: he was portrayed as a person who had hardly any knowledge beyond his settlement or county; his 'homeland' more often than not ended with his family plot or village. The texts extensively advertised the advantages of the army life: travel, acquiring knowledge of the world, a diverse and interesting life, greater hygiene, education and opportunity to master some craft and so on. In other words, if while entering the army soldiers were "wrongheaded foolish peasants," they would leave it as "sufficiently educated persons who know something and are capable to many different things." ${ }^{22}$ In Serbia, the pattern of contrast between the peasant and the army world was to a certain extent similar.

For several decades, Serbian publications aimed at soldiers neither dwelled nor explicitly theorized on notions of nation or 'fatherland.' Instead, the literature adopted a more traditional approach: it chose to employ recurrent folkhistorical motives. Different editions preferred to print epic songs and romantic tales on the medieval history of the Serbs. For example, $49 \%$ of the content of the first six issues of Uzdanica (233 out of 480 pages) was filled with epic folkhistorical stories. ${ }^{23}$

Narration on the greatness and the fall of the medieval Serbian kingdom performed nation-forming functions in Serbia that in Bulgaria were accomplished by special texts on the fatherland or on contemporary patriotic deeds. In Serbia the songs and stories on the time of Stefan Dushan, on the 1389 Battle of Kosovo or on 'the new Miloš Obilićs' of the nineteenth century occupied large portions of the literature published for the soldiers. The quintessence of this approach was formulated in the reasoning that "the Serbian song is an educative reader, which contains everything elevated and good that merited mentioning at the time."24

\footnotetext{
22 Voynishka sbirka, 1, 1893-1894, 196.

23 Uzdanica, 1(1-6), 1901.

24 Andrej Živanović, Čemu vojnika uči naša narodna poezija (Belgrade: Državna štamparija, 1892), 59 .
} 
This practice was applied not only in the army but also among younger children enrolled in the educational system. Textbooks in different subjects, and especially those in Serbian language and literature, included original epic texts drawn from the volumes of folk songs collected by Vuk Karadžić and his followers. These songs by and large narrated the story of the medieval Serbian state and its fate before and after the Battle of Kosovo in $1389 .{ }^{25}$ From the 1890 s on this method was further expanded and remodelled. The new textbooks incorporated not only original folk songs but also new epic-inspired texts fusing folklore with recent history and geography. Manuals painted the picture of cyclically recurrent historical time: the example of the heroes of the Battle of Kosovo was as relevant to the nineteenth or twentieth as to the fourteenth century. For example, the heroic figures of the early-nineteenth-century antiOttoman Serbian uprisings were represented as a new version of the fourteenth century originals. Manuals underlined that in 1878 the Serbian army had managed briefly to retake the area, but that the real 'Kosovo revenge' was an immediate aim for the future. ${ }^{26}$ Thus Serbians, both as children in school and while becoming adults in the army, were exposed to the same type of national inculcation based on folklore and epic values. The texts-both for the pupils and the soldiers-outlined the superiority of combativeness, bravery and strength in war over other human qualities.

The re-creation of the nation through the mold of epic folklore was dominant throughout the whole period, although it lost some momentum in the last decade before the Balkan Wars. From the turn of the century another 'modern' approach was modestly introduced: texts started explicitly to describe and define not the epic past, but the contemporary Serbian fatherland and nation. From around 1908 such accounts were regularly included in the books for soldiers: ${ }^{27}$ 'the fatherland' was related to the ancestors (described as "graves of

25 [Filip Hristić], Treća čitanka za osnovne srpske škole (Belgrade: Državna štamparija, 1869), 117-142. Later edition: Četvrta čitanka za osnovne srpske škole (1885), 2-28; [Stojan Novaković], Srpska čitanka za niže gimnazije i realke, Kniga prva (3rd edition, Belgrade: Državna štamparija, 1883). In the latter textbook, aimed at 12-14 year old children, 21 texts out of 85 (occupying 91 pages out of 363 ) were epic songs on the times of the medieval Serbian state, including the Battle of Kosovo.

26 Milan Marković and B. Nedić, Srpska čitanka za treći razred osnovnih škola Kraljevine Srbije (2nd edition, Belgrade: Državna štamparija, 1894), 30-46, 106-109; Ljubomir Protić and Vladimir Stojanović, Srpska čitanka: treća knjiga za četrvti razred osnovnih škola u Kraljevini Srbiji (Belgrade: Državna štamparija, 1907), 3, 201-205; Milan Šević, Srpska čitanka za sredne škole. Knjiga prva za prvi razred (Belgrade: Državna štamparija, 1907), 75-80.

27 Pavle Jurišić, Vojnička čitanka (Beograd: Štamparija Davidović, 1908), 7-9; Dragoljub Mihajlović, Srpski soko. Knjiga za vojnike (Beograd: Uredništvo Narodnih novina, 1908), 
grandfathers," or "a country, in which every spot is permeated with the blood of your grandfathers and fathers") in continuity with, but more importantly also as a departure from, the previous epic folk model. 'The fatherland' was associated with the natural beauty of the land to a lesser extent than was the case in Bulgaria; in Serbia, the binding of the peasant soldier with the new 'imagined community,' the building of the bridge between the old village worldview and the modern reality, was accomplished with the help of different practices. Rather, 'the fatherland' was associated with the initial biological perceptions of the individual, with the place and moment of his birth. ${ }^{28}$ It also encompassed the pre-modern restricted horizon of the young peasant, both social (relatives, friends and co-villagers) and material (hearth, house, family plot, entire village). The texts relayed the message that "one who loves his village loves also his fatherland; one who defends his co-villagers defends also his people." 29

The notion of 'the village' was also important in the writings of Ion Creangă, one of Romania's nation-builders; ${ }^{30}$ by contrast, 'Ottoman childhoods' were not obsessed with the village world (even Kâzım Karabekir with his grandfather's village). The alternative neighborhood [mahalle] community is more often than not inscribed into the town-dwelling space. This suggests contrasts between values of peasant societies of Serbia, Bulgaria and Romania and that of late Ottoman cum Turkish entity. ${ }^{31}$

In Serbia, the image of the kin relations was also deployed to sum up various motivations: "Fatherland, dear mother, we are your children. When you call us we will come, when you want it we will die."32 The association 'soldiers = children' was highly symbolical but also appropriate and practical in view of the youth of the recruits. It ensured entering into the world of adulthood with the partial incorporation and continuation of a child's perceptions. ${ }^{33}$

9-10; Jovan Sretenović, Potrebna znanja za vojnike stalnoga kadra (Beograd: Štamparija Srbija, 1908), 21; Jokić, Vojnički bukvar (12th edition), 75.

28 Uzdanica, 3, 1903, 179-180; Jurišić, Vojnička čitanka, 7; Sretenović, Potrebna znanja, 21; Mihajlović, Srpski soko, 9; Dimitrije Pejović, Vojnička čitančica za svakog vojnika (Zaječar: Štamparija Đura Jakšić, 1911), 77 .

29 Ibid., 34.

$30 \quad$ See Alex Drace-Francis, this volume.

31 See Philipp Wirtz, this volume.

$32 \quad$ Uzdanica, 1, 1901, 346-347.

33 It should be noted that in the Serbian case, direct associations of the nation with 'big family' were very rare. One exception, however, was the article "Thoughts of Great People on Fatherland and Army," Uzdanica, 10, 1910, 319-320. This provided a straightforward definition: "The fatherland is one big family." The same text was published in the Bulgarian 
The Bulgarian approach was somewhat different. From its very first publications, soldier literature did not include folk texts but made elaborate efforts to recreate and affirm the specially outlined contemporary notion of 'fatherland,' which was inherently bound with the nation. Numerous novels explicitly aimed to evoke this new image in the soldier. The fatherland was presented as a land, a natural beauty, an elevated pleasant feeling; it was anthropomorphous, eternal, homogeneous, stable, static and stemming from the history and the spirit of the ancestors. The variety of emotions and symbols might seem diverse, eclectic and disorganized, yet they all merged into a single dominating image, directly embodying and presenting the essence of the 'people': the family. The imagining of the nation was most easily accomplished by depicting a kin-related community, a 'second family' (alongside the first, biological one) or a 'big family.' According to two texts:

The Bulgarian nation [narod] is a big family; we, all Bulgarians, are members, relatives; we speak one language, share one faith and the same mores and customs, and we live in one land — Bulgaria, which is our Fatherland. ${ }^{34}$

Our Bulgarian land is like a big house, inhabited by one big family, that is called a Bulgarian nation $[$ narod $] .^{35}$

Heidi Morrison (this volume) highlights the importance of the notion of family in nation-building efforts aimed at Egyptian children; in the case of Bulgaria, the 'family-resemblant' national concept was employed in the army rather than among schoolchildren. In Serbia, the kin-related comparisons were also emphasized but texts stopped short of the direct association of the nation with a 'big family.'

The second quote above reveals one very important aspect of Bulgarian national self-representation: 'fatherland' (and nation) as a land. This trope was employed frequently both in the army and the school system, though with somewhat different emphases. For the young children it was mainly the natural beauty of Bulgaria's plains and hills, rivers and mountains, forests and meadows, sun and sky — both on the level of birthplace intimacy and on more

magazine for soldiers eleven years earlier, as "Thoughts and Sayings on the Fatherland, on Love for the Fatherland and for the Flag," (Voynishka sbirka, 6, 1899, 490-496). Both texts were probably translated from another European language; the Bulgarian officer establishment more quickly adopted this foreign approach to nation-building. Dimităr Draganov, Uchebnik za mladite voynitsi (Sofia: Pechatnitsa Gavazov, 1907), 43. Voynishka sbirka, 1, 1893-1894, 357. 
abstract and larger, but specifically named, geographical units, such as the Stara planina, Rila and Pirin Mountains, the Danube, Maritsa and Vardar Rivers, the Thracian Plain. ${ }^{36}$ Especially instrumental were the verses and prose of the leading contemporary writer Ivan Vazov, whose nature-loving motives and particular geographic symbols permeated school-book pages. One of the most successful texts was his verse composition 'Where is Bulgaria?' which was widely reprinted in textbooks and reached to the core of the Bulgarian imagination:

If men ask me where the sunrise

Warmed me first when I was small,

If men ask me where the land is

That I cherish most of all,

This will be my simple answer:

Where the mighty Danube flows,

Where the Black Sea brightly dances

In the East and stormy grows;

$[\ldots]$

My Bulgaria, dear mother,

Land with earthly goods galore,

Land I cherish like no other,

Please accept my humble bow. ${ }^{37}$

The notion of land was also extensively employed in the literature for Bulgarian soldiers, but often with somewhat different nuances. Apart from innocent

$3^{6} \quad$ For national appropriation of the land/scapes, see Anthony Smith, The Ethnic Origin of Nations (Oxford: Blackwell, 1986), 183-191; Colin Williams and Anthony Smith. "The National Construction of Social Space," Progress in Human Geography, 7 (4), 1983, $502-518$.

37 Dragan Manchov, Bashtin ezik za detsa. Tretya godina. Tretya chitanka za uchene sled bukvaryat (11th edition, Plovdiv: D.V. Manchov, 1886), 148; Nikola Saranov, Chitanka za osnovnite uchilishta. Sredni kurs. Vtora godina (7th revised edition, Plovdiv: Hr. G. Danov, 1894), 59; Todor Vlaykov, Chitanka za chetvărto otdelenie (6th edition, Sofia: Vălkov, 1896), 23-24; Ivan Ivanov, Chitanka za treto otdelenie (2nd edition, Tărnovo: Knizh. N.P. Nedyalkovich, 1897), 82; Găcho Baltadzhiev, Chitanka za chetvărto otdelenie (2nd revised edition, Plovdiv: Hr. G. Danov, 1911), 95. The full text of the verse includes references to many more geographical notions. The first part of the translation is by Peter Tempest, published in Ivan Vazov, Selected Poems (Sofia: Sofia Press, 1976), 21, while that of the last strophe is by Valentin Hadzhiyski (Gergana Songbook [Sofia: State Agency for Bulgarians Abroad, 2013], 9). 
abstract natural beauty and the country as a whole, it denoted mostly the particular 'real' holdings close to the peasants' worldview: an agricultural plot or a meadow, a small forest or a modest house, a vineyard or a garden. Thus 'the fatherland' became tantamount to the sum of the different real estates, "inherited from our fathers by all of us, who bear the beautiful name "Bulgarians."'38 The entrance into the world of adulthood meant increasing concern for and dependence on property ownership, and the nation had to be associated with it.

Army education as a rule emphasized the ethnic nation as a community built on a common language, religion, customs, origins and history, rather than on a concept of the common state and its institutions and territories. Therefore, the ideal fatherland - the territorial projection of the nation-stretched far beyond the current state borders. While Bulgarian officers stressed the San Stefano Greater Bulgaria as the model for a 'united fatherland'39 their Serbian counterparts presented the numerous 'Serbian lands' to that end; the full official list included the then-current small Kingdom of Serbia, together with Bosnia, Herzegovina, Srem, Banat, Bachka, Old Serbia, Macedonia, districts of Vidin and Sredets [Sofia], as well as Montenegro, Dalmatia, Slavonia and Croatia. ${ }^{40}$ In this respect both Bulgarian and Serbian army educators were following and affirming concepts that were already imposed on children by the geography textbooks in school. ${ }^{41}$

From the mid-189os the Bulgarian soldier was increasingly introduced mainly to one particular 'unredeemed' territory: Macedonia. After the turn of the century, reflecting geopolitical and ethnographic patterns, Macedonia predominated over the other parts of the ideal Bulgarian fatherland. In contrast, Serbian officers could not point exclusively to any single region, yet four out of the thirteen 'Serbian lands' received somewhat privileged attention: 'Old Serbia' (encompassing approximately Kosovo and the adjacent territories

38 Todor Girginov, Pisma do mladite voynitsi (Sofia: Voenen zhurnal, 1902), 14-15.

39 That is, Bulgaria as according to the 1878 San Stefano treaty including the Principality of Bulgaria, Eastern Rumelia, Macedonia and South (Adrianople) Thrace, Morava valley [Eastern Serbia] and North Dobrudja. This model was presented in: [Peev], Voynishka chitanka (Plovdiv: Druzhestvena pechatnitsa Edinstvo, 1888), 49; Ivan Markov, Nravstveni besedi s voynitsite (Sofia: Pridvorna pechatnitsa, 1891), 110-111; Girginov, Pisma, 17-18; Konstantin Shingarov, Uchebnik za rednitsite (5 $5^{\text {th }}$ edition, Sofia: Pridvorna pechatnitsa, 1907), 21.

$40 \quad$ Uzdanica, 4, 1904, 695; Miloš Vasić, Vojnička čitanka (2nd edition, Belgrade: Štamparija Svetozara Nikolića, 1896), 15; Jurišić, Vojnička čitanka, 7-9; Sretenović, Potrebna znanja, 21, 65; Mihajlović, Srpski soko, 9; Pejović, Vojnička čitančica, 66.

Kaytchev, Makedoniyo, văzzhelana, 148-150. 
under the Ottomans), Macedonia, Bosnia and Herzegovina. All of these until 1908 were really or theoretically within the Ottoman Empire, a space of instability and expected territorial change. Initially the focus was to the south, towards the first two regions, but starting from around 1903, and especially after 1908, the northwest and Bosnia and Herzegovina received equal consideration.

The sole notable discrepancy facing the Bulgarian soldier was that between the imagined larger ethnic nation and the potential civic community that might emerge from the current Bulgarian state and its institutions. The soldier was extensively introduced and educated in the functions of the state, its prince (after 1908, the king), its army and other institutions. This line sometimes evolved into a systematic concept of the political nation that by definition was in contradiction with the genetic organic nation. ${ }^{42}$ Yet in general the majority of officers preferred to stress the ethnic essence of the nation.

This was further reinforced by neglecting the ethnic 'others' in the Bulgarian army. A substantial portion of Bulgarian citizens were Turks and other ethnic minorities, but the literature for the soldiers did not aim to socialize them with the state and its army. ${ }^{43}$ The sole text explicitly devoted to a non-ethnic Bulgarian soldier was that on a Jew named Boroh who demonstrated bravery in the battle as a drummer and scared the enemy, the Turkish military unit. ${ }^{44}$

Likewise, the Serbian authors paid no special attention to the accommodation of non-Serbs in the army. The military authorities took steps to assimilate the Vlach conscripts from northeastern Serbia but this process was not reflected in the literature for soldiers. The Serbian officers took for granted the ethnic nature of the Serbian nation, which was not undermined by any references to the nation-state. Their major challenge in defining and presenting the Serbian nation to the soldier was quite different: it was extremely difficult to determine the proper role of religion as a constituent element of the national community.

Traditionally, the Serbian national community was deeply steeped in Eastern Orthodox Christianity. Dominating folklore texts underlined epic heroes like Lazar Hrebljanović, Miloš Obilić, Marko Kraljević, who were Orthodox Christians fighting the Muslim Turks. These images initially also

\footnotetext{
42 Voynishka sbirka, 1, 1893-1894, 527-528.

43 One of the rare exceptions is Macho Iskrov, Pamyatna kniga za rednitsite of bălgarskata voyska (5th edition, Varna: R.L. Blǎskov, 1901), 11. The text mentions Bulgarian citizens and soldiers who could be of Bulgarian, Turkish, Greek or another ethnicity.

44 Voynishka sbirka, 10, 1903, 107-120. The text in fact was translated from Russian, but in the context of the numerous conflicts with Turkey it was perceived by the readers-soldiers as reflecting the reality of Bulgaria and its army.
} 
permeated literature for the Serbian soldier; however, Serbian military educators soon clearly understood that Serb- and Croat-speaking Muslims or Catholics in the West should be somehow incorporated rather than excluded. Therefore the texts included vast sections narrating on the irrelevancy of confessional divisions:

This difference in faith is not a big difference. The blood remains Serbian blood in all of us. We remain true brothers because we are knit together first of all by blood, language and customs; very rarely some other people have them as commonly shared as us.

A rhyming phrase was formulated to reinforce the effect: "The brother is dear irrespective of the faith." ${ }^{\text {45 }}$ Later editions of the most popular soldier's primer even omitted the section on Orthodox religion; instead, the new text explained that Serbs and Croats, despite differences in religion and name, constitute one and the same people. ${ }^{46}$ Nevertheless, even novel depictions of the nation and its fatherland included the Orthodox faith, monasteries and saints as important markers. ${ }^{47}$ Thus Serbian identity remained insecure on the question of religion; while it remained fundamentally linked to Orthodoxy, on the surface some efforts were made to induce in soldiers a different view. Ultimately, Catholic Croats and Bosnian Muslims were not included efficiently in the imagined national community of the Serbian soldier.

By way of conclusion, these nation-building tropes can be juxtaposed to contemporary theoretical classifications. The army writers in both countries saw themselves as portraying and explaining the inherent, coherent and consistent nature of their nation; this recreated national type was dissimilar to the ideal models of Herder or Renan. When exceptional, more theoretically inclined, authors borrowed from foreign sources they did not revere to them as highest wisdom: the foreign elements were simply considered as necessary ingredients for the imagined unique nation. The Serbian and Bulgarian officers perceived the nation both as an objective and as a subjective phenomenon. ${ }^{48}$

45 "Brat je mio pa bilo koje vere bio," Vasić, Vojnička čitanka, 14-15.

46 Jokić. Vojnički bukvar (7th edition, 1901), 91-96; id. (12th edition, 1911), 75-76.

47 Sretenović, Potrebna znanja, 21; Mihajlović, Srpski soko, 9-10; Petar Bojović, Vaspitavanje vojnika (Belgrade: Vojno Ministarstvo [War Ministry], 1907), 132.

48 "In all these places we will encounter our brothers-Bulgarians who speak the same language, are of the same belief, have the same customs and manners, the same feelings and thoughts for the common Bulgarian Fatherland." [Dobri Ganchev], Voynishka hristomatiya (Sofia: Voynishka sbirka, 1896), 53. 
Their model was so encompassing that it sometimes explicitly included communicational abilities that could not be derived solely from either objective or subjective influences alone:

we feel [...] towards them [compatriots] as at our home, in our village or in our town: we could converse soul by soul, we could understand each other; [...] everyone understands my word, everyone reads, writes, speaks and sings like me and I understand everyone. ${ }^{49}$

In other worlds, the nation was also represented and embodied in what Karl Deutsch would have defined as 'communicational complementarity. 50

\section{Picturing the Neighbors, Modelling the Foes: The Nation's Significant Others and the Ottoman Empire}

In both Bulgaria and Serbia, the way army educators defined their nation also implied a particular image of their neighbors. Some neighbors were significant as 'others,' and or as potential enemies.

Among the different neighboring countries, Romania received the least attention. In Serbia, the state across the Danube, and even the Romanianspeaking community at home, were not specially denoted in soldierly readings; clearly, Romania was perceived neither as potential enemy nor as trusted ally. The country was barely mentioned in Bulgaria either: the main exception was that when describing the 'ideal fatherland' of San Stefano Bulgaria, literature for soldiers shortly observed that one part of this area (a section of northern Dobrudja) was allocated to Romania according to the Berlin Treaty. ${ }^{51}$ Aside from that brief note, the themes connected with the northern neighbor were largely neglected. After the turn of the century Romania started to insist on territorial compensations in Bulgarian southern Dobrudja in the event of redistribution of the Ottoman inheritance in the Balkans; yet the Bulgarian soldier was not prepared to imagine facing an invading army from the north. This also points to the lack of any organized lobby group in Bulgarian society

49 Voynishka sbirka, 1, 1893-1894, 527.

5o Karl Deutsch, Nationalism and Social Communication (2nd edition, Cambridge, MA: MIT Press, 1966), 96-98.

51 Girginov, Pisma, 18; Shingarov, Uchebnik, 21; Vasil Guzhgulov, Novobranetsăt. Kak da se gotvi za voenna sluzhba (Shumen: Tipogr. Sp. Popov, 1903), 46; Guzhgulov, Voynishki drugar (2nd edition, 1907), 47-48. 
that might include the Romanian-Dobrudjan issue in the political agenda of Bulgaria and its army.

Greece was covered more extensively in Bulgaria. Traditionally, Greece was portrayed mainly negatively, as it had been a main competitor in the Middle Ages; more importantly, the very construction of the modern Bulgarian nation was accomplished through emancipation from the Greek-dominated Rum millet. In addition, both states were engaged in rivalry over the domination of parts of Ottoman-ruled Macedonia, culminating in 1904-1908 with armed clashes between Bulgarian komiti and Greek andartes. ${ }^{52}$ However, in spite of this, the Bulgarian soldier did not receive extensive adversary texts aimed at Greece. Compared with the heated anti-Greek rhetoric of the contemporary Bulgarian public and its press, the literature for soldiers was quite moderate when presenting Greek violence in Macedonia. Probably the small distant kingdom to the south was not perceived by Bulgarian political and military leaders as a potential immediate war enemy. Before encountering the Greek army, already defeated in 1897 , the Bulgarian soldier had to overcome the resistance of the immediate direct neighbor to the south: the Empire with quite more impressive military strength.

Serbian army education paid less attention to the Greeks. They appeared only as casual opponents of the medieval Serbian kingdom of Stefan Dushan, ${ }^{53}$ but were not represented in the key Kosovo epic cycle. Intensive political contacts at the beginning of the twentieth century could not compensate for a lack of military exchanges and the relative geographical remoteness.

More important were the mutual images of the two Slav nations. In Bulgaria, the picture of the Serbs was complex. On one hand, the 1885 Serb-Bulgarian war was the first test of the young Bulgarian army, and could not be forgotten. Also, Sofia faced Serbian counteractivity and resistance to Bulgarian domination in the northern parts of Ottoman Macedonia, and some of the texts for soldiers reflected this rivalry. On the other hand, though, accounts of the 1885 war did not focus negatively on the adversary as such, preferring instead to advance the virtues of the Bulgarian soldiers and their officers. Similarly to the Romanian case, the issue of areas of San Stefano Bulgaria under Serbian control was by and large ignored. Even in the texts on atrocities against Macedonian Bulgarians, Serbia emerged as a minor nuisance, compared to the main villains-Ottoman Turkey, and to a certain extent Greece. Moreover, some editions began to publish items that explicitly promoted a favourable

Voynishka sbirka, 9, 1902, 349, 394, 499-533; 13, 1906, 688; 15, 1908, 945-949; Guzhgulov, Voynishki drugar (4th edition, 1909), 137-138; id. (8th edition, 1912), 127. 
image of the Serbs. In 1906-1907 the Bulgarian magazine for soldiers even published series of translated Serbian texts! The obvious aim was to present the related destiny of the two neighboring peoples and their shared suffering under the Turks, to prepare the ground for solidarity, mutual help and alliance. Army educators apparently realized that the sole realistic prospect for acquiring Macedonia involved a military alliance with Serbia; henceforth, the contradictions had to be disregarded in order to describe the closeness of the potential allies. ${ }^{54}$

In contrast, the Serbian image of their eastern Slav neighbor was neither complex nor favorable. Bulgarians were presented as the natural adversary of Serbia, deprived of the most elevated virtue of the Serbs: bravery. They were the enemy in the 1885 war, occupiers of one of the 'Serbian lands' of Vidin and Sredets [Sofia] and the current foe in Macedonia, presented as old Serbian land. This negative image was additionally reinforced by selectively chosen historical episodes, such as the 1330 battle near Velbuzhd (Kyustendil) or the controversy over the ethnicity of the leader of the early-nineteenth centuryinsurgent units in the area of Timok during the First Serbian Uprising. ${ }^{55}$ Nevertheless, the Bulgarians were rarely presented as a typical adversary who would unavoidably become a war enemy: this role was preserved for the 'Turks' and the 'Austrians.' Bulgaria was more of a minor, 'reserve' enemy who might strike some unexpected blow from the rear.

The Habsburg Empire had a very special place in the imagining of the Serbian soldier. The Empire ruled over the most of the 'Serbian Lands,' including regions with unregulated international jurisdiction: Bosnia and Herzegovina. Therefore, in theory 'the Austrians' (sometimes referred also as 'Germans,' in certain cases in union with 'the Hungarians') should be the most significant factor for the military educators. However, their image as a potential enemy was not especially elaborated during the decades up to the end of the nineteenth century, and even until 1908. The reasons for this were twofold. Firstly, the epic cycles on Marko Kraljević and the Battle of Kosovo, long the core tools for building Serbian identity, pointed to the south and did not include specific references to the Catholic neighbors beyond the Danube and Sava. Secondly, the post-1878 Serbian state directed its foreign policy priorities to the south and went into a secret alliance with Austria-Hungary to that effect. Therefore it was highly unadvisable to criticize the mighty northern ally. Though some very rare books for Serbian soldiers dared to create an image of

\footnotetext{
54 Voynishka sbirka, 1, 1893-1894, 420-436; 13, 1906, 931-940; 14, 1907, 1-18, 107-118, 217-228; 15, 1908, 945-949; 19, 1912, 575 .

55 Uzdanica, 3, 1903, 231-236; 10, 1910, 633-640; 11, 1911, 147-153; Jurišić, Vojnička čitanka 17, 35; Vasić, Vojnička čitanka, 13, 40.
} 
an all-powerful adversary to the north, the shift in that direction was very slow. ${ }^{56}$ The decisive transformation came as late as 1908 , along with the Bosnian crisis. The preceding (since 1903) foreign policy shift in an anti-Austrian and pro-Russian direction now was overtly exposed. The change could be spectacularly observed in a soldier-reader by Pavle Jurišić. The first edition was published in the early 1908, several months before the crisis, employing the traditional nation-narrating model on a vast fatherland consisting of many 'Serbian Lands' but emphasizing southern national roots in Old Serbia and Macedonia. A new edition had to be printed very quickly, reflecting a strategic change of government policy and of the everyday routine of its citizens. A new section, 'Our Lands under the Foreigners' was produced: it devoted eight times more space to regions under Austria-Hungary than to those in the Ottoman Empire and Bulgaria. Since the editing and re-writing of the main body of the reader seemed too arduous an task, the author chose an easier solution. He reprinted the main text but added at the top of every page a catchword on Bosnia and its "enslavers." Thus the phrase "Proud Bosnia weeps in slavery" was employed 12 times and "Austrians are our biggest adversaries" 10 times. In fact, the book offered two different chronological layers with diverging geographical messages. ${ }^{57}$ In the remaining four years up to the wars, Serbian officers extensively focused on Bosnia and Vienna's unjust rule of over it. Nevertheless, at the same time stories of the Turkish adversary suppressing southern Serbdom in Macedonia and Old Serbia continued unabated.

For both Serbia and Bulgaria, the foremost potential enemy, and simultaneously the most significant 'other,' was doubtless the Ottoman Empire. Its image was elaborated more extensively than those of the three other young small Balkan states taken together. In Bulgaria, 'the Turks' were the historic 'enslavers,' subjecting Bulgaria to a "five-century-long yoke." Crucially, this image was extrapolated into the contemporaneity, to the Turkish oppression of the Bulgarians in Macedonia. ${ }^{58}$ Sometimes the negative image of the southern neighbor was presented with novel arguments. A story entitled "In What Kind of Banks we Put our Money" narrated a Bulgarian teacher in Ottoman Macedonia arrested and jailed by local police because of his books. The main purpose of the law enforcement officers was to receive a bribe, and after paying it from his modest savings the teacher was released. Thus the Ottoman Empire emerged as a

\footnotetext{
56 Ibid., 15 .

57 Jurišić, Vojnička čitanka (2nd edition, 1909), 8-11, 18-19, 59, 64, 87, 94, 111-112.

$5^{8}$ Voynishka sbirka, 1, 1893-1894, 221-227; 10, 1903, 580-588; 13, 1906, 312, 769; 14, 1907, 955-970, 980-993; 19, 1912, 477-401; Todor Kantardzhiev, Primeri po voennoto văzpitanie (Plovdiv: Tărg. pechatnitsa, 1906), 153-170.
} 
synonym of the incompetence, arbitrariness and venality of the officials, as a byword of institutionalized administrative and economic backwardness. The authors self-proclaimed a sense of superiority over their decaying oriental neighbor: "In Bulgaria applications are not accepted without treasury stamps, in Turkey-without rushvet, (rüşvet, bribe)."59 All these negative images were complemented with the representation of the enemy fighting Bulgarian soldiers. The numerous stories of nineteenth-century revolutionary struggles were used to that effect, continuing with stories about the Bulgarian militia corps in the $1877-1878$ Russian-Ottoman war and the soldiers of the contemporary Bulgarian army, either fighting in border skirmishes or ready for a general war against the enemy.

In Serbia, the image of 'the Turk' was almost the same: in the epic cycles the enemy was always a Moslem-Turk, a long time "tyrant," "enslaver," "persecutor." Similarly, Ottoman rule over Old Serbia and Macedonia was presented in the blackest colors. ${ }^{60}$ Serbians officers, however, were not very consistent in narrating stories on contemporary border Serb-Turkish conflicts.

Overall, in both countries the Ottoman Empire dominated texts for soldiers and was close to completely assuming the role of the enemy. However, while for Bulgarian officers and soldiers it was the sole adversary, for their Serbian counterparts, as discussed above, Austria-Hungary emerged as a second major threat towards 1908. To complicate matters further, the image of another lesser foe appeared as well: the Albanians. They were presented as a distinct people, but as Muslims were semi-attached to the image of the Ottoman Turks. ${ }^{61}$

In both Bulgaria and Serbia, efforts aimed at children at school had somewhat different priorities. The main emphasis was on the composition and integration of the image of the nation, with texts very rarely explicitly focused on attitudes towards a specific neighbor. Opposition to and emancipation from the dominating neighbor were expressed inasmuch as to ensure the formation and working of a full-blown national self-identity. In the Serbian case, the epic songs on the Battle of Kosovo often involved the image of the Muslim/ Ottoman Turk enemy. In Bulgaria, textbooks sometimes incorporated stories on nineteenth-century revolutionaries fighting against the Ottoman rule, or indignantly described the continuing oppression over compatriots in Macedonia.

59 Voynishka sbirka, 12, 1905, 14-26.

6o Pejović, Vojnička čitančica, 98-105; Uzdanica, 4, 1904, 258-259, 561-562; 10, 1910, 331, 639; 11, 1911, 68-72, 147-153.

61 Uzdanica, 1, 1901, 338; 2, 1902, 65-72, 298-301; 4, 1904, 641-646, 656-664. The article "Our Neighbors Albanians," was the sole text presenting them in the positive light, Uzdanica, $10,1910,350-356$. 
Some texts on medieval Bulgarian kings raised the image of a Byzantine Greek adversary or included verses rejecting the Greek and affirming the Bulgarian origin of the Saints Cyril and Methodius, who were instrumental in the establishment of the Old Bulgarian Christian culture. ${ }^{62}$ After the turn of the new century some Serbian textbooks started to print items on the imminent war against the Ottomans. ${ }^{63}$ In general, however, most school images aimed at children were used exclusively to build the national self and could not be compared in intensity and importance to the sustained military efforts to create a threatening figure of adversary.

In both countries all army images of the 'the other' were sets of stereotypes that condensed real facts into oversimplifying and misleading schemes ultimately building and affirming self-identity, and asserting difference and superiority over 'the others.' This pattern of stereotypes has been described as

the guarantee of our self-respect; [...] the projections upon the world of our own sense of our own value, our own position and our own rights. The stereotypes are [...] the fortress of our tradition, and behind its defenses we can continue to feel ourselves save in the position we occupy. ${ }^{64}$

The stereotyped pictures of important others were indispensable to shaping and defining one's own national identity, particularly in the reading of army educators.

To what extent were the sustained efforts of the two young states and their armies to convert boys into accomplished adults, peasants into patriotic soldiers, effective? To what extent they did shape the new mass national consciousness? Statistics point to the large quantitative outreach of the military and educational systems. ${ }^{65}$ The ultimate results became evident in early autumn of 1912: the outbreak of the First Balkan War was universally acclaimed in both countries. Widespread evidence confirms that the populations of both countries enthusiastically supported the war effort in the name of the nation and its dreamed-of unification. This suggests that, at least in the decades up to

62 Todor Ikonomov, Chitanka za prigotvyanie na urotsite v klassovete (Ruse: Pechatnitsa na v. Slavyanin, 1885), 138; Nikola Altănkov, Chitanka za IV otdelenie (Sofia: Liberalen klub na B. Kozhuharov, 1892), 38-39, 69-71, 104-105; Saranov, Chitanka za osnovnite uchilishta, 123-141.

63 Protić and Stojanović. Srpska čitanka, 14, 195-222; id. (6th revised edition, 1912, 185-211).

64 Walter Lippmann, Public Opinion (New York: Harcourt, Brace and Company, 1922), 96.

65 See footnotes 9,12 and 15 above. 
the Balkan Wars and the First World War, the army, school and other nationbuilding institutions in Serbia and Bulgaria were by and large effective. The results of their labors were undermined at later stages: starting with initial disillusions during Balkan Wars, deepening in the trenches and battlefields of the First World War and continuing during its harsh aftermath.

\section{Bibliography}

\section{Legal Sources}

"Law on the Recruitment of the Permanent Army, October 23, 1872," in Zbornik zakona i uredaba izdanih u Knjažesvu Srbiji. Belgrade: State Printing House, 25, 1872,63 .

"Law on Material Support and Educational Rearrangement of Schools, May 21, 1880," Dărzhaven vestnik, 2 (45) May 28, 1880.

"Law on Taking New Recruits in the Bulgarian Army," Dărzhaven vestnik, 2 (89), December 6, 1880.

"Law on Primary Schools, December 31, 1882," Prosvetni glasnik, 4 (2), January 31, 1883, $41-51$.

"Law on the Organization of the Army," Srpske novine, 50 (24), 115, February 1, 1883.

"Law on Acknowledgement of Illegitimate Children, of their Legitimization and on Adoptions," Dărzhaven vestnik, 12 (9), January 12, 1890.

"Law on Inheritance," Dărzhaven vestnik, 12 (20), January 25, 1890.

"Naredba okružne komande," Beogradske opštinske novine, 8 (33), August 5, 1890.

"Law on guardianship," Dărzhaven vestnik, 12 (67), 1-5, March 24, 1890.

"Law on the Organization of the Military Forces of the Bulgarian Army," Dărzhaven vestnik, 14 (36), February 15, 1892.

"Law on the Organization of the Military Forces of the Bulgarian Army," Dărzhaven vestnik, 14 (36), February 15, 1892.

"Objava," Beogradske opštinske novine, 17 (9), March 7, 1899.

"Law on the Organization of the Army, January 27, 1901," in Zbornik zakona i uredaba u Kraljevini Srbiji, Belgrade: State Printing House, 61, 1903, 92-93.

"Law on the Amendment of the Law on the Organization of the Army, April 15, 1902," Službeni vojni list, 22 (16), April 20, 1902, 301.

"Law on Marriage of Officers, Under Officers, Corporals and Privates, December 24, 1901," Zbornik zakona i uredaba u Kraljevini Srbiji. Belgrade: State Printing House, 61, 1903, 400-404.

"Law on the Organization of the Military Forces of the Bulgarian Army," Dărzhaven vestnik, 14 (18), January 24, 1904.

“Objava," Beogradske opštinske novine, 22 (36), August 22, 1904. 
"Exarchate's Statute Adapted for the Principality of Bulgaria," in Velichko Georgiev and Stayko Trifonov, Istoriya na bălgarite 1878-1944v dokumenti, 1 (1), Sofia: Prosveta, 1994.

\author{
Journals \\ Voynishka sbirka \\ Uzdanica
}

\title{
Other Primary Sources
}

Altănkov, Nikola, Chitanka za IVotdelenie, Sofia: Liberalen klub na B. Kozhuharov, 1892.

Baltadzhiev, Găcho, Chitanka za chetvărto otdelenie, 2nd revised edition, Plovdiv: Hr.G. Danov, 1911.

Bojović, Petar, Vaspitavanje vojnika, Belgrade: Vojno Ministarstvo [War Ministry], 1907. Draganov, Dimităr, Uchebnik za mladite voynitsi, Sofia: Pechatnitsa Gavazov, 1907.

[Ganchev, Dobri], Voynishka hristomatiya, Sofia: Voynishka sbirka, 1896.

Girginov, Todor, Pisma do mladite voynitsi, Sofia: Voenen zhurnal, 1902.

Guzhgulov, Vasil, Novobranetsăt. Kak da se gotvi za voenna sluzhba, Shumen: Tipogr. Sp. Popov, 1903.

Guzhgulov, Vasil, Voynishki drugar. Uchebnik za voynitsite ot vsichki rodove voyski, Sofia: Balkanska tribuna, 1st edition; 1907; 2nd edition, 1907; 4th edition, 1909; 8th edition, 1912.

Hadzhiyski, Valentin, Gergana Songbook. Sofia: State Agency for Bulgarians Abroad, 2013.

[Hristić, Filip], Treća čitanka za osnovne srpske škole, Belgrade: Državna štamparija, 1869. Later edition: Četvrta čitanka za osnovne srpske škole, 1885.

Ikonomov, Todor, Chitanka za prigotvyanie na urotsite v klassovete, Ruse: Pechatnitsa na v. Slavyanin, 1885 .

Iskrov, Macho, Pamyatna kniga za rednitsite of bălgarskata voyska, $5^{\text {th }}$ edition, Varna: R.L. Blǎskov, 1901.

Ivanov, Ivan, Chitanka za treto otdelenie, 2nd edition, Tărnovo: Knizh. N.P. Nedyalkovich, 1897 .

Jokić, Kosta, Vojnički bukvar, Belgrade: Državna štamparija, 1893; 7th edition, 19o1; 12th edition, 1911.

Jurišić, Pavle, Vojnička čitanka, Belgrade: Štamparija Davidović, 1908; 2nd edition, 1909.

Kantardzhiev, Todor, Primeri po voennoto văzpitanie, Plovdiv: Tărg. pechatnitsa, 1906.

Manchov, Dragan, Bashtin ezik za detsa. Tretya godina. Tretya chitanka za uchene sled bukvaryat, 11th edition, Plovdiv: D.V. Manchov, 1886.

Markov, Ivan, Nravstveni besedi s voynitsite, Sofia: Pridvorna pechatnitsa, 1891.

Marković, Milan and B. Nedić, Srpska čitanka za treći razred osnovnih škola Kraljevine Srbije, 2nd edition, Belgrade: Državna štamparija, 1894. 
Mihajlović, Dragoljub, Srpski soko. Knjiga za vojnike, Belgrade: Uredništvo Narodnih novina, 1908.

[Novaković, Stojan], Srpska čitanka za niže gimnazije i realke, Kniga prva, 3rd edition, Belgrade: Državna štamparija, 1883 .

"Our Neighbors Albanians," Uzdanica, 10, 1910, 350-356.

[Peev], Voynishka chitanka, Plovdiv: Druzhestvena pechatnitsa Edinstvo, 1888.

Pejović, Dimitrije, Vojnička čitančica za svakog vojnika, Zaječar: Štamparija Đura Jakšić, 1911.

Protić, Ljubomir and Vladimir Stojanović, Srpska čitanka: treća knjiga za četrvti razred osnovnih škola u Kraljevini Srbiji, Belgrade: Državna štamparija, 1907; 6th revised edition, 1912.

Saranov, Nikola, Chitanka za osnovnite uchilishta. Sredni kurs. Vtora godina, 7 th revised edition, Plovdiv: Hr. G. Danov, 1894.

Šević, Milan, Srpska čitanka za sredne škole. Knjiga prva za prvi razred, Belgrade: Knjižara Geca Kona, 1907.

Shingarov, Konstantin, Uchebnik za rednitsite, $5^{\text {th }}$ edition, Sofia: Pridvorna pechatnitsa, 1907.

Sistematicheski sbornik na zakonite, ukazite i tsirkulyarite po voennoto vedomstvo ot 1877/78 do r yanuarii 19or g., Sofia: Voenno Ministerstvo [War Ministry], 1901.

Sretenović, Jovan, Potrebna znanja za vojnike stalnoga kadra, Belgrade: Štamparija Srbija, 1908.

Statisticheskigodishnik na Bălgarskoto tsarstvo (Sofia: Glavna Direktsiya na Statistikata [Directorate General of Statistics], 4, 1912).

Statistički godišnjak Kraljevine Srbije 4: 1898-1899, Belgrade: Državna Štamparija Kraljevine Srbije, 1902.

Statistički godišnjak Kraljevine Srbije 12: 1907-19o8, Belgrade: Državna Štamparija Kraljevine Srbije, 1913.

"Thoughts and Sayings on the Fatherland, on Love for the Fatherland and for the Flag," Voynishka sbirka, 6, 1899, 490-496.

"Thoughts of Great People on Fatherland and Army," Uzdanica, 10, 1910, 319-320.

Tsonkov, Dimo, Razvitie na osnovnoto obrazovanie v Bălgariya ot 1878 do 1928, Sofia: Ministerstvo na narodnoto prosveshtenie [Ministry of National Education], 1928.

Vasić, Miloš, Vojnička čitanka, 2nd edition, Belgrade: Štamparija Svetozara Nikolića, 1896. Vazov, Ivan, Selected Poems, translated by Peter Tempest, Sofia: Sofia Press, 1976.

Vlaykov, Todor, Chitanka za chetvărto otdelenie, 6th edition, Sofia: Vǎlkov, 1896.

Živanović, Andreja, Čemu vojnika uči naša narodna poezija, Belgrade: Državna štamparija, 1892.

\section{Secondary Literature}

Bjelajac, Mile, "Ženidbe oficira srpske i jugoslovenske vojske 1881-1941. Planirano stvaranje elite," Godišnjak za društvenu istorïu [Annual of Social History], 2 (1), 1995, 19-28. 
Ćunković, Srećko, Školstvo i prosveta u Srbiji u XIX veku, Belgrade: Pedagoški muzej, 1971.

Deutsch, Karl, Nationalism and Social Communication, 2nd edition, Cambridge, MA: MIT Press, 1966.

Heywood, Colin, Growing Up in France: From the Ancien Régime to the Third Republic, Cambridge: Cambridge University Press, 2007.

Jelavich, Charles, South Slav Nationalisms: Textbooks and Yugoslav Union before 1914, Columbus: Ohio State University Press, 1990.

Kaytchev, Naoum, Makedoniyo, văzzhelana: armiyata, uchilishteto i gradezhăt na natsiyata $v$ Sărbiya i Bălgariya [Desired Macedonia: Army, School and Nation-Building in Serbia and Bulgaria, 1878-1912], Sofia: Paradigma, 2003; 2nd edition, 2006.

Lippmann, Walter, Public Opinion, New York: Harcourt, Brace and Company, 1922.

Milićević, Milić, "Socijalno poreklo oficirskog kadra školovanog u Srbiji od 1850 do 1901 godine," Godišnjak za društvenu istoriju [Annual of Social History] 2 (2), 1995, 194-201.

Milićević, Milić, “Vitalni činioci razvoja srpske vojske tokom XIX veka," Vojinoistorijski glasnik, 41 (1-2), 1993, 45-55.

Özkirimli, Umut, Theories of Nationalism: A Critical Introduction, New York: Palgrave Macmillan, 2010.

Perrot, Michelle, Philippe Ariès and Georges Duby (eds), A History of Private Life: From the Fires of Revolution to the Great War, Harvard: Harvard University Press, 1990.

Ratković-Kostić, Slavica, "Stvaranje stajače vojske u Srbiji i njena uloga u Timočkoj buni 1883 godine,"Vojinoistorijski glasnik, 44 (1-2), 1996, 24-29.

Smith, Anthony, "Gastronomy or Geology? The Role of Nationalism in the Reconstruction of Nations," Nations and Nationalism, 1, 1995, 3-23.

Smith, Anthony, The Ethnic Origin of Nations, Oxford: Blackwell, 1986.

Weber, Eugen, Peasants into Frenchmen: The Modernization of Rural France 1870-1914, Stanford: Stanford University Press, 1976.

Williams, Colin and Anthony Smith. "The National Construction of Social Space," Progress in Human Geography, 7 (4), 1983, 502-518.

Wright, Herbert, The Constitutions of the States at War 1914-1918, Washington, DC: Government Printing Office, 1919. 